\title{
GRADUACIÓN DE MÉdICOS ESPECIALISTAS Agosto 14 de 2009
}

\author{
José Ignacio Hernández C. MD*
}

e ha correspondido el honor de dirigir estas palabras a un grupo de jóvenes médicos que hoy se titulan Especialistas en las diversas ramas de la medicina.

Con este motivo nos encontramos reunidos en el aula máxima Guillermo Fergusson con un grupo de personas para celebrar este triunfo: los padres, esposas, familiares y amigos que ven cumplidas sus ilusiones y anhelos. Los altos directivos de la Facultad y de los Hospitales que se sienten satisfechos de haber facilitado y respaldado este proyecto educativo. Los graduandos que están seguros de haber recibido la mejor preparación integral. Los profesores que como artesanos han dedicado todos sus esfuerzos, su tiempo y conocimientos para hacer de cada uno de ustedes un profesional idóneo y eminente.

Tengo la certeza de que han elegido la mejor institución para este propósito. Desde ya pertenecen a esta gran familia y a esta centenaria casa que es el Hospital de San José. Están plenos de conocimientos y de desarrollos tecnológicos y en las mejores condiciones para ejecutar a cabalidad el acto médico.

Espero que no participen ciegamente en el frío concepto de hombre máquina-facturación, no busquen el reconocimiento a través de factores externos, no se hundan en la sociedad de consumo que sólo ve en el dinero sus

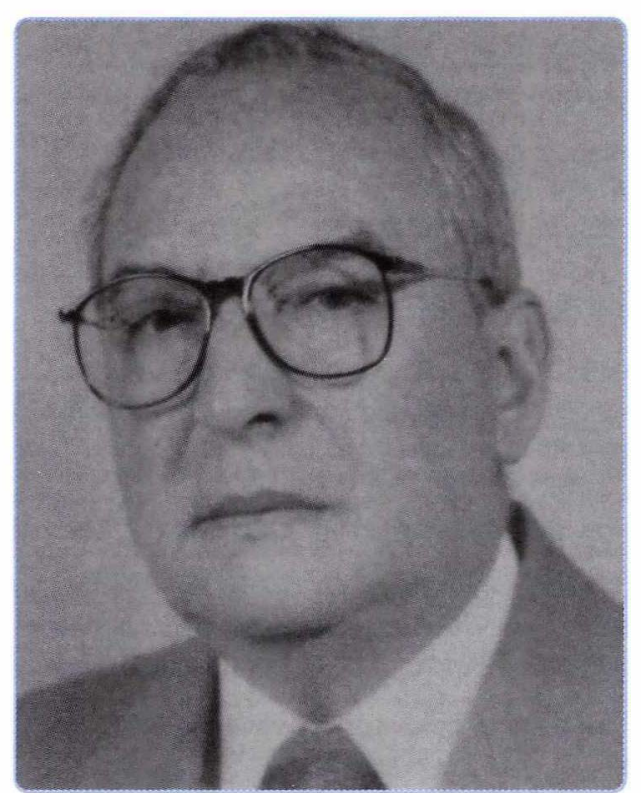

metas y objetivos. Ustedes son diferentes, tienen bien cimentados y estructurados sus valores éticos y morales, entienden al hombre y al universo, se interesan y entusiasman con la ciencia, la investigación y el humanismo.

Si estos elementos se conjugan, el reconocimiento, el respeto y la admiración serán su recompensa por haber cumplido con dignidad la verdadera vocación médica.

Jefe del Servicio de Medicina Interna, profesor titular Fundación Universitaria de Ciencias de la Salud, Hospital de San José. Bogotá DC. Colombia. Miembro de Número de la Sociedad de Cirugía de Bogotá. 